\title{
Sacubitril/Valsartan: The Role of Neprilysin Pathway in Heart Failure
}

\author{
Sidhi L. Purwowiyoto ${ }^{1,2}$, Ferina Angelia ${ }^{3}$, Ananta S. Prawara ${ }^{4}$ \\ ${ }^{1}$ Cardiac Catheterization Laboratory, Department of Cardiology and Vascular Medicine, \\ RSUD Pasar Rebo, East Jakarta, Indonesia, ${ }^{2}$ Faculty of Medicine, Universitas Muhammadiyah \\ Prof. DR. Hamka, Tangerang, Indonesia, ${ }^{3}$ Faculty of Medicine, Universitas Kristen Krida \\ Wacana, Jakarta, Indonesia, ${ }^{4}$ Faculty of Medicine, Universitas Diponegoro, \\ Semarang, Indonesia
}

\begin{abstract}
Neprilysin (NEP) is an enzyme present in several body cells and is involved in the degradation of natriuretic peptides (NPs), bradykinin (BK), and adrenomedullin (ADM). Furthermore, sacubitril/ valsartan (LCZ696), the first agent of Angiotensin Receptor Neprilysin Inhibitor (ARNI), has been developed to inhibit both Renin Angiotensin Aldosterone System (RAAS) and NEP. This study, therefore, aimed to discuss the role of sacubitril/valsartan in inhibiting the progression of heart failure (HF) by influencing the RAAS and NEP pathways. Data on previous articles related to basic theory and clinical trials of ARNI were collected through multiple search engines using the inclusion criteria: articles published in the English language within 2010 to 2020, while additional information on HF guidelines, RAAS, NPs, and ADM were acquired separately. Subsequently, a total of 30 studies were selected and further discussed. According to the results, NEP inhibition leads to a rise in the level of vasodilator agents and is beneficial for HF patients previously prescribed solely RAAS inhibiting agent (Angiotensin Converting Enzyme, ACE-inhibitor and Angiotensin II Receptor Blockers, ARB). In addition, the RAAS, as well as the NEP pathways play a significant role in HF progression and are inhibited by sacubitril/valsartan. Also, clinical trials showed sacubitril/valsartan is superior to ACEinhibitor and ARB in clinical trials in treating, as well as reducing the morbidity and mortality rates of patients suffering from HF with reduced ejection fraction (HFrEF).
\end{abstract}

Keywords: ARNI, heart failure, neprilysin, sacubitril/valsartan

\section{Sacubitril/Valsartan: Peran dari Jalur Neprilisin dalam Gagal Jantung}

\begin{abstract}
Abstrak
Neprilisin (NEP) merupakan sebuah enzim yang dapat ditemukan di berbagai sel pada tubuh dan terlibat dalam mendegradasi peptida natriuretik, bradykinin (BK), dan adrenomedullin (ADM). Sacubitril/ valsartan (LCZ696) merupakan agen pertama dari Angiotensin Receptor Neprilysin Inhibitor (ARNI) yang dikembangkan untuk menghambat jalur Renin Angiotensin Aldosterone System (RAAS) dan NEP. Review ini bertujuan untuk membahas peranan dari sacubitril/valsartan dalam menghambat progresi gagal jantung dengan memengaruhi jalur RAAS dan NEP. Pengumpulan data untuk teori dasar dan uji klinis ARNI dalam artikel review ini menggunakan beberapa mesin pencari. Informasi tambahan seperti pedoman-pedoman gagal jantung, RAAS, peptida natriuretik, dan ADM didapatkan secara terpisah. Kriteria inklusi yang digunakan adalah studi harus berbahasa Inggris dan dipublikasikan antara 2010 dan 2020. Sebanyak 30 studi diinklusi dan dibahas lebih lanjut dalam review ini. Hasilnya didapatkan bahwa inhibisi dari NEP menyebabkan terjadinya peningkatan agen-agen vasodilator yang berdampak positif bagi pasien gagal jantung yang sebelumnya direkomendasikan meminum obat yang hanya menghambat RAAS (penghambat Angiotensin Converting Enzyme/ACE dan Angiotensin II Receptor Blockers/ARB). Sacubitril/valsartan menghambat alur RAAS dan NEP yang mana keduanya memainkan peranan penting dalam progresi gagal jantung. Sacubitril/valsartan lebih superior dalam mencapai target pengobatan pasien yaitu mengurangi morbiditas dan mortalitas pasien gagal jantung dengan penurunan fraksi ejeksi dibandingkan dengan penghambat ACE dan ARB pada uji-uji klinis.
\end{abstract}

Kata kunci: ARNI, gagal jantung, neprilisin, sacubitril/valsartan

Correspondence: dr. Sidhi L. Purwowiyoto, Sp.JP(K), FIHA, Faculty of Medicine, Universitas Muhammadiyah Prof. DR. Hamka, Tangerang, Banten 13460, Indonesia, email: sidhilaksono@uhamka.ac.id Submitted: 24 ${ }^{\text {th }}$ June 2020, Accepted: $1^{\text {th }}$ February 2021, Published: 30 ${ }^{\text {th }}$ June 2021 


\section{Introduction}

Heart failure (HF) is a clinical cardiac syndrome caused by structural and functional defects in cardiac tissues which impair the function of the heart on ventricular filling or ejecting blood out of the heart. ${ }^{1}$ The increasing prevalence, various complications, high mortality rate, and rapidly expanding cost have made HF a major concern for physicians and cardiologists worldwide. ${ }^{2}$ There is no definitive treatment available currently, the aim of the treatment is to increase the quality of life by reducing morbidity and mortality. ${ }^{3}$

Angiotensin Converting Enzymeinhibitor (ACE inhibitor) or Angiotensin II Receptor Blockers (ARB) has been used as a first line treatment in reducing the morbidity and mortality of HF patients since both have been proven to affect the Renin Angiotensin Aldosterone System (RAAS) system effectively. ${ }^{4}$ However, the Prospective Comparison of ARNI with ACEI to Determine Impact on Global Mortality and Morbidity in Heart Failure (PARADIGM-HF) study brought a new perspective of using sacubitril/valsartan (the first agent of Angiotensin Receptor Neprilysin Inhibitor/ARNI) instead of enalapril (ACE-inhibitor) for HFrEF patients, the result showed statistical significance and the trial had to be terminated because of it. ${ }^{5}$ In the Heart Failure Association (HFA) of the European Society of Cardiology (ESC) 2019 and the American Heart Association/American College of Cardiology/Heart Failure Society of America (AHA/ACC/HFSA) 2017 HF guideline, ARNI had been mentioned as a first line treatment option for HF patients. ${ }^{6,7}$ Beside inhibiting the RAAS system through valsartan, ARNI is inhibiting the NEP pathway through sacubitril. ${ }^{5}$

NEP was first discovered as an enzyme in the brush border of the kidney. Since then, more research was conducted to figure out the role of NEP in human body. NEP was found to have substrate specificity to many synthetic and natural peptide substrates including enkephalines, tachykinins, endothelins, bradykinin (BK), adrenomedullin (ADM) and natriuretic peptides (NPs). Thus, inhibition of NEP has the potential to be the treatment of cardiovascular diseases, pain, and inflammation., ${ }^{5,8}$ Circulating NEP was determined to be uncapable of acting as biomarker in HF patients, but its inhibition was consistently found to be beneficial and therapeutic in HF patients. ${ }^{6-9}$ This review will discuss further the role of NEP pathway in HF, clinical trials of sacubitril/valsartan, and the role of RAAS, NPs, BK, and ADM in HF that was affected by sacubitril/valsartan.

\section{Methods}

In this review, we search for basic theory and clinical trials of ARNI. The searching was done using multiple search engine including Pubmed, EBSCOhost, Cochrane, Google, dan Google Scholar. The keyword used were "Angiotensin Receptor Neprilysin Inhibitor", "Heart Failure", and "Neprilysin pathway". Additional information such as HF guidelines, RAAS, NPs, and ADM were acquired separately. The inclusion criteria used were the study should be written in English and published within 2010 to 2020. A total of 30 studies were included and further discussed in this study (Figure 1).

\section{RAAS in Heart Failure}

The RAAS involves significantly in the pathophysiology of HF, especially in $\mathrm{HFrEF}{ }^{10}$ The purpose of RAAS activation is to meet the demands of vital organ systems. ${ }^{11}$ It is activated in response to three main stimuli which are decreased arterial blood pressure, decreased intracellular chloride levels inside macula densa cells, and sympathetic activation. ${ }^{12}$ The stimuli triggered the release 


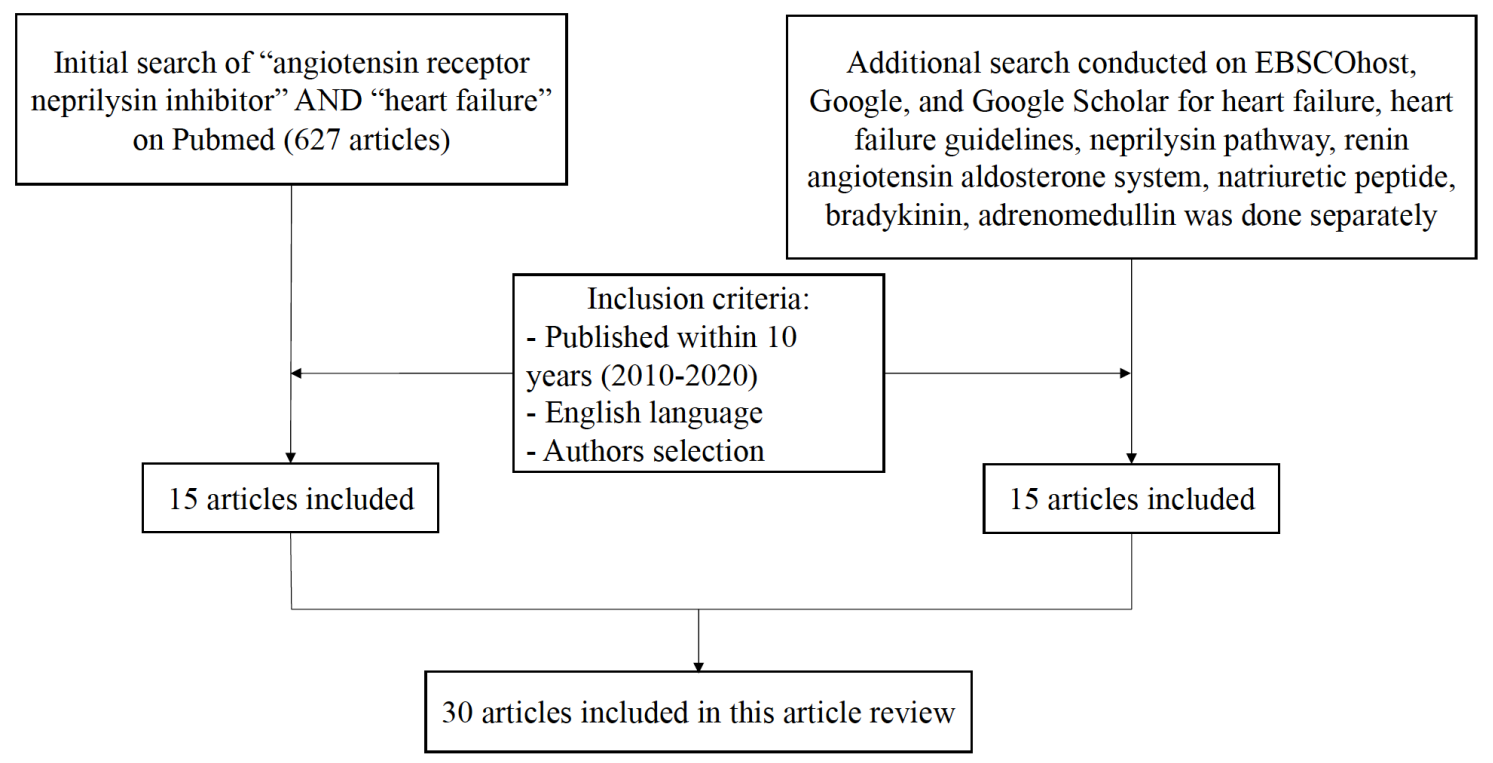

Figure 1 The Method Used in Article Finding

of Renin from juxtaglomerular cells, which then convert the Angiotensinogen from the liver to Angiotensin I. Angiotensin I with the help of Angiotensin Converting Enzyme from the lungs is converted into Angiotensin II, then Angiotensin II binds to Angiotensin II type I receptor (AT1R) and causes its activation. The activation of AT1R caused several effects; salt and water retention, renal arteriolar vasoconstriction, vascular smooth muscle contraction, sympathetic activation, $\mathrm{ADH}$ secretion, and aldosterone secretion. ${ }^{10,11}$ The short term activation of the system may be beneficial, but a long term chronic stimulation to the system cause harmful effect to the heart which leads to the progression of HF. ${ }^{13}$ Up until now, the first line treatment for HFrEF patients is by inhibiting the RAAS. In the latest HF guidelines by ESC 2016 and ACC/AHA/HFSA 2017, ACE inhibitor, ARB and ARNI are recommended to be the first line treatment. ${ }^{6,7}$

\section{NPs, BK, and ADM in Heart Failure}

Atrial natriuretic peptide (ANP) and brain natriuretic peptide (BNP) are the NPs from the natriuretic systems found in the heart. ANP is synthesized and stored in the cardiac atria until there is a stimulus of atrial stretching, then it will be released. ${ }^{14}$ Besides, hormones like endothelin, Ang, and arginine-vasopressin can also stimulate the release of ANP. ${ }^{15}$ The level of BNP is expressed as the highest in the ventricular myocardium. ${ }^{14}$ However, it is stored minimally in ventricles' granules and the granules are triggered to burst by the stimulation of cardiac wall stretching caused by either increased transmural gradient or volume overload. ${ }^{15,16}$ Both NPs, when bind to NP receptors, play a significant role as an ideal counter-regulatory mechanism to the effect of HF by inhibiting the secretion of endothelin and the effect of Ang II including systemic vasoconstriction, sodium re-absorption in proximal tubule, and aldosterone secretion. Therefore, NPs regulate the renal blood flow, sodium excretion, and vasoconstrictive agents to inhibit the progression of HF. ${ }^{15}$

BK has cardioprotective effect in patients with HF. The concentration of circulating BK significantly increased and by acting through B-2 receptors, it causes vasodilation and improves LV relaxation and contractile 
performance. ${ }^{17}$ In contrary, an excess of BK accumulation as a result of ACE-inhibitor inhibition to BK catabolism may bring harmful effects such as cough, rash, hypotension, and angioedema. $^{18}$

ADM is a 52 amino acid peptide with one intramolecular disulfide bond and a carboxyterminal amide structure that was formed after peptide cleavage signal from preproADM to proADM and then to ADM. ADM is a potent renal vasodilator that is degraded by neutral endopeptidase $24 .{ }^{11}$ or NEP. Thus, the effect of ADM can be potentiated by administering NEP inhibitor, which was proven by a research conducted by Hubers and Brown in the animal model (dogs). Furthermore, the potentiation of natriuresis and diuresis effect of intravenous ADM was also found in a HF model in sheep administered with NEP inihibitor. ${ }^{19}$

\section{Inhibition of Neprilysin Pathway}

NEP is an enzyme that is referred by many names (neutral endopeptidase, membrane metalloendopeptidase, and enkephalinase) and is widely expressed in endothelial cells, smooth muscle cells, cardiac myocytes, renal epithelial cells, and fibroblasts. ${ }^{20,21}$ NEP is involved in one of the degradation processes of NPs through enzymatic degradation. ${ }^{15}$ NEP inhibitor was first attempted to potentiate the effect of NPs in 1989 using two formulations: oral (racecodotril) and intravenous (candoxatril). ${ }^{22}$ However, in chronic use, the effects provided by NPs were neutralized by the increasing concentration of Ang II. ${ }^{22,23}$ Later it was known that NEP plays a significant role in catalyzing both vasodilator and vasoconstrictor peptides. ANP, BNP, $\mathrm{BK}$, and $\mathrm{ADM}$ are included in the vasodilator peptides, while endothelin-1 (ET-1) and Ang II are included in the vasoconstrictor peptides. The limited number of peptides that can be degraded by the NEP suggest that the catalytic site of NEP is specific and may have a varying affinity to each peptide. ${ }^{21}$ It was then figured that ANP, Ang I and Ang II are among the highest affinities and BNP, ET-1 and BK are the lowest affinities for NEP. ${ }^{24}$ Thus, it can be concluded that by only inhibiting NEP will increase both NPs and Ang II, which did not give a significant impact to HF patients. ${ }^{22,23}$ The inhibition of NEP pathway can be seen in Figure 2.

\section{ARNI}

The discontinuation of Omapatrilat, a combination of NEP inhibitor and ACEinhibitor, because of its negative effect, led to another combination of drugs: ARB and NEP. It was named sacubitril/valsartan (LCZ696), the first drug of ARNI class. It was believed to have more inhibition to BK because it did not inhibit ACE (which degrade BK) and sacubitrilat, the active metabolite of sacubitril, did not inhibit aminopeptidase $\mathrm{P}$, which also degraded BK and, in the end, lowering the risk of angioedema. ${ }^{22}$ Sacubitril/valsartan also have a similar positive effect to Omapatrilat; inhibiting the RAAS and inhibiting the NEP pathway which is believed to enhance the level of NPs, BK, and ADM. ${ }^{5}$ Furthermore, sacubitril/valsartan administration caused more NPs (ANP and BNP) to bind with its receptor and activated the generation of cGMP which enhanced diuresis, natriuresis, and myocardial relaxation. ${ }^{20}$ ARNI role in inhibiting RAAS and NEP pathway can be seen in Figure 2.

LCZ696 consists of valsartan and NEP inhibitor prodrug AHU377, which will be metabolized to LBQ657. Valsartan and AHU377 both were absorbed quickly after administration. Valsartan was reaching its maximum plasma concentration within 1.6 to 4.9 hours, while AHU377 was absorbed quicker, by reaching its maximum plasma concentration within 0.5 to 1.1 hours. AHU377 was going to 


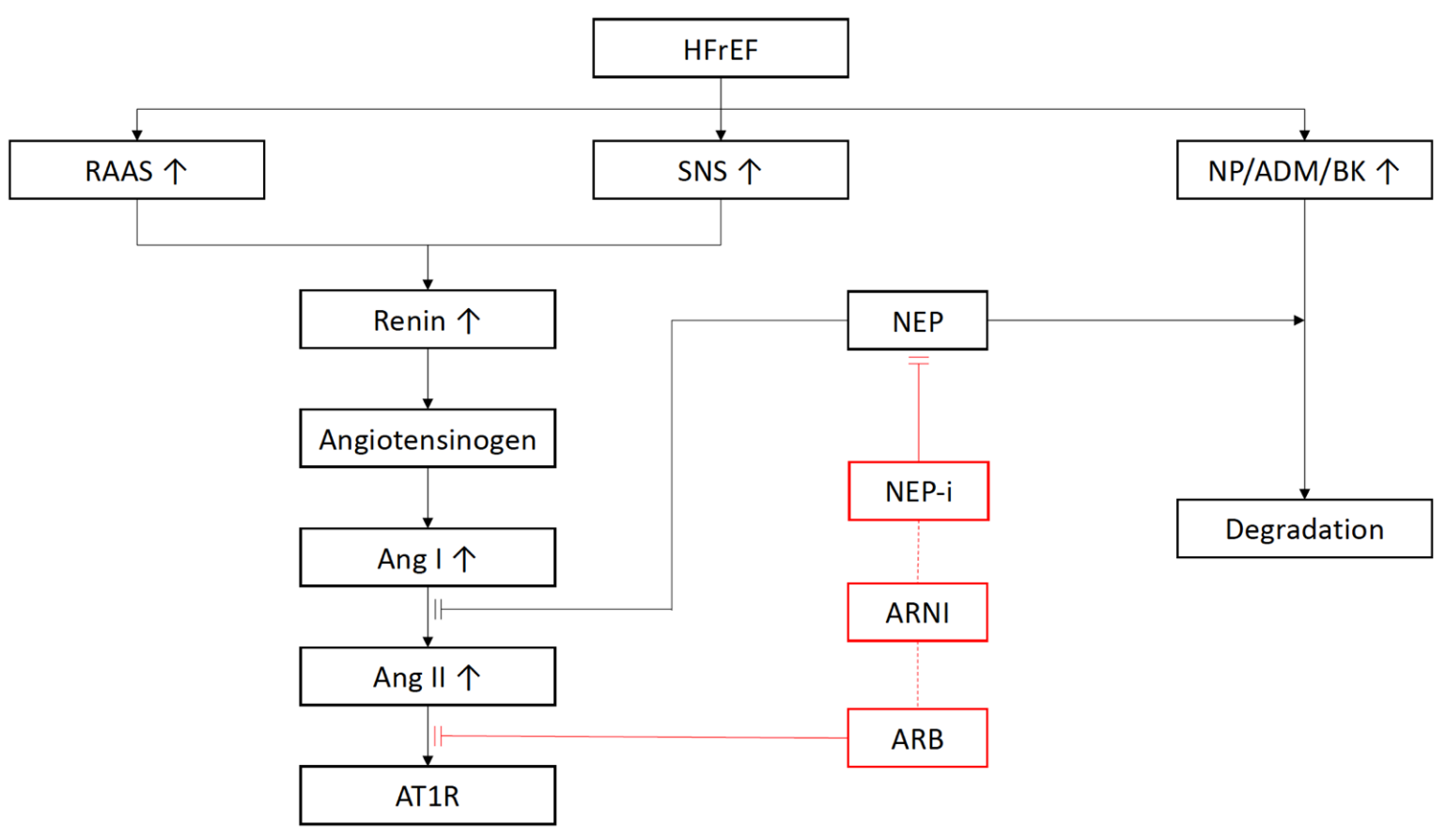

Figure 2 Heart Failure Reduced Ejection Fraction (HFrEF) Pathway Blocked by NEP Inhibitor and ARB

ADM, Adrenomedullin; Ang, Angiotensin; ARB, Angiotensin II Receptor Blocker; ARNI, Angiotensin Receptor Neprilysin Inhibitor; AT1R, Angiotensin II Receptor Type I; BK, Bradykinin; NEP, Neprilysin; NEP-i, Neprilysin Inhibitor; NP, natriuretic Peptide; RAAS, Renin Angiotensin Aldosterone System; SNS, Sympathetic Nervous System

be converted to LBQ657 and it took 1.8 to 3.5 hours for LBQ657, AHU377's active form, to reach its maximum plasma concentration. The mean half time for AHU377, Valsartan, and LBQ657 were 1.1 to $3.6,8.9$ to 16.6 , and 9.9 to 11.1 hours, respectively. The administration of LCZ696 was associated with an increase in plasma cGMP, renin, and angiotensin II, which proved that the drug inhibits both NEP pathway and the angiotensin receptor. The drug was considered to be tolerated even with a dose as high as $1200 \mathrm{mg}$ for a single dose and $900 \mathrm{mg}$ once daily for multiple doses. ${ }^{20}$ Besides, sacubitril/valsartan was determined to be both effective during fasted and fed states. ${ }^{25}$ Sacubitril/valsartan was then tested in several clinical trials.

Doctors can initiate sacubitril/valsartan 49/51 mg twice daily when the patient is currently taking ACE-inhibitor/ARB or without severe renal/moderate hepatic impairment, but if the patient has one or more conditions stated previously then the initial dose can be reduced as low as 24/26 mg twice daily. After the initiation, hypotension and potassium need to be monitored every 1-2 weeks and the dose can be titrated up to the optimal dosage (97/103 mg twice daily) within 14-28 days. If the patient is currently taking ACE-inhibitor, there should be a 36 hours washout period. ${ }^{20,25}$

\section{Clinical Trials of Sacubitril/Valsartan (LCZ696)}

There are six clinical trials up until now known to figure the effect of ARNI in several conditions. The first trial conducted was The Prospective Comparison of ARNI with ARB on Management of Heart Failure with Preserved Ejection Fraction (PARAMOUNT) HF with a total of 308 HF NYHA II-III patients with preserved ejection fraction ( $\mathrm{EF} \geq 45 \%$ ). The study concluded that LCZ696 was better 
than valsartan in reducing NT-proBNP in HF patients with preserved ejection fraction (HFpEF) at 12 weeks, however the difference becomes not statistically significant at 36 weeks and there was no significant change in echocardiography findings. ${ }^{26}$ PARADIGM trial was the second trial with a large number of patients involved (8442 patients). This study found that LCZ696 or sacubitril/ valsartan was superior compared to enalapril in reducing risks of death and hospitalization for New York Heart Association (NYHA) IIIV HFrEF patients $(\mathrm{EF} \leq 40 \%)$. The superiority was supported by the evidence that there was no serious hospitalization with airway compromise case reported from 19 patients with angioedema $(0.4 \%){ }^{5}$

Safety and Tolerability of Initiating LCZ696 in Heart Failure Patients (TITRATION) was a study that determined the best uptitration of LCZ696 from two regimens: 3 weeks of uptitration (condensed) and 6 weeks (conservative) of uptitration LCZ696 dose. The authors reported that conservative group gives slightly better outcome with more treatment and tolerability success and less adverse events, but the because the differences were not significant, it was concluded that both regimens had a tolerability profile in line with other HF treatments. ${ }^{27}$ Comparison of Sacubitril/Valsartan Versus Enalapril on Effect on NT-proBNP in Patients Stabilized From an Acute Heart Failure Episode (PIONEER HF) study compared the effect of sacubitril/valsartan with enalapril on NTproBNP of stabilized acute HFrEF patients. The change in NT-proBNP concentration was higher in sacubitril/valsartan group than enalapril group significantly in week 4 and $8 .^{28}$

Efficacy and Safety of LCZ696 Compared to Valsartan, on Morbidity and Mortality in Heart Failure Patients with Preserved Ejection Fraction (PARAGON HF) study compared sacubitril/valsartan with valsartan on NYHA II-IV HFpEF patients. Sacubitril/valsartan shown fewer cases in hospitalizations for HF and death from cardiovascular causes compared to valsartan, but the difference was not significant statistically. ${ }^{29}$ Comparison of Pre- and Post-discharge Initiation of LCZ696 Therapy in HFrEF Patients After an Acute Decompensation Event (TRANSITION) study aimed to assess the tolerability and optimal time point to initiate sacubitril/valsartan in patients stabilized after acute HF. This study found that either sacubitril/valsartan was given in the hospital (pre-discharge) or shortly after discharge (post-discharge) both were feasible for the patients. Nearly half of the patients achieved 97/103 mg doses of sacubitril/ valsartan within 10 weeks. ${ }^{30}$ Further details of the six studies are included in Table 1.

\section{Side Effects of Sacubitril/Valsartan}

Hypotension, renal dysfunction, and hyperkalemia are most common side effects found in the six clinical trials. The percentage of the side effects vary among each clinical trial; hypotension was reported between $9.7 \%$ to $19 \%$, hyperkalemia $7.7 \%$ to $16.1 \%$, and renal dysfunction $1 \%$ to $13.6 \% .^{5,26-30}$ Hypotension is common in ARNI because the inhibition of NEP potentiates NP levels which contributed to greater vasodilation. However, hypotension did not cause the patients to stop using the drug in the PARADIGM study. ${ }^{20}$ The major concern of the use of Omapatrilat was the incidence of life-threatening Angioedema and ARNI was proved to overcome the issue. Angioedema cases were reported in 1 to 18 patients and most of the trials reported that the patients with Angioedema did not have compromise airway. ${ }^{5,26-30}$

\section{Limitation}

Sacubtril/valsartan can still be considered as a novel drug. There may be new clinical trials that can explain further the use and effect of 
Table 1 Patients' Demographic

\begin{tabular}{|c|c|c|}
\hline & PARAMOUNT HF ${ }^{26}$ & PARADIGM $^{5}$ \\
\hline Year published & 2012 & 2014 \\
\hline Study design & $\begin{array}{l}\text { Randomized, parallel-group, } \\
\text { double-blind multicenter trial }\end{array}$ & $\begin{array}{l}\text { Double-blind treatment } \\
\text { multicenter trial }\end{array}$ \\
\hline No. of patients & 308 & 8442 \\
\hline Aim of study & $\begin{array}{l}\text { Comparing LCZ696 with } \\
\text { valsartan in NYHA II-III } \\
\text { HFpEF patients }(E F \geq 45 \%)\end{array}$ & $\begin{array}{l}\text { Comparing LCZ696 with } \\
\text { enalapril in NYHA II-IV } \\
\text { HFrEF patients (EF } \leq 40 \% \text { ) }\end{array}$ \\
\hline Outcome & $\begin{array}{l}\text { 1. Change in NT-proBNP: } \\
\text { better in LCZ696 with } \\
\text { a significant difference } \\
\text { in week } 12(\mathrm{p}=0.005) \\
\text { and without significant } \\
\text { difference in week } 36 \\
(\mathrm{p}=0.020) \\
\text { 2. No change in } \\
\text { echocardiography } \\
\text { evaluation }\end{array}$ & $\begin{array}{l}\text { 1. Fewer in death from } \\
\text { cardiovascular causes or } \\
\text { first hospitalization for } \\
\text { worsening HF in LCZ696 } \\
\text { compared with enalapril } \\
\text { with } \mathrm{p}<0.001 \\
\text { 2. Death from any cause } \\
\text { was less in LCZ696 than } \\
\text { enalapril with } \mathrm{p}<0.001 \\
\text { 3. Lower change in KCCQ } \\
\text { clinical summary score } \\
\text { at } 8 \text { months in LCZ696 } \\
\text { compared with enalapril } \\
\text { with } \mathrm{p}<0.001 \\
\text { There was no significant } \\
\text { difference between both } \\
\text { groups in new-onset atrial } \\
\text { fibrillation ( } \mathrm{p}=0.83 \text { ) and } \\
\text { decline in renal function } \\
\text { (p=0.28) }\end{array}$ \\
\hline
\end{tabular}

Adverse event 1. Death, hypotension, renal dysfunction or hyperkalemia were reported in both groups

2. 22 patients $(15 \%)$ administered with sacubitril/valsartan and 30 patients $(20 \%)$ with valsartan had one or more serious adverse event
1. 29 cases of angioedema were identified (19 in LCZ696 and 10 in enalapril) but none with a serious airway problem

2. There was more hypotension and elevated serum creatinine $\geq 2.5$ $\mathrm{mg} / \mathrm{dl}$ in patients with LCZ696
TITRATION $^{27}$

2016

Randomized, parallel-group, doubleblind multicenter study

540

Comparing the uptitration of LCZ696 from $50 \mathrm{mg}$ to $200 \mathrm{mg}$ twice daily in 3 weeks (condensed) and 6 weeks (conservative) in NYHA II-IV HFrEF patients $(\mathrm{EF} \leq 35 \%)$

1. The incidence of hypotension (9.7\% vs $8.4 \%)$ and hyperkalemia ( $7.7 \%$ vs $4.4 \%)$ were higher in the condensed group compared with the conservative group.

2. The incidence of renal dysfunction was slightly higher in the conservative group $(7.6 \%$ vs $7.4 \%$ )

3. The treatment success of the condensed group was $77.8 \%$ and the conservative group was $84.3 \%$ when excluding non-AE/ non-death-related discontinuation, $\mathrm{n}=466$ )

4. The tolerability success (all patients achieved and maintained a dose of LCZ696 $200 \mathrm{mg}$ twice daily minimum 2 weeks) of the condensed group was $83 \%$ and the conservative group $87.3 \%$

1. Two cases of angioedema were identified (one in the run-in period and one in the postrandomization) and neither case was involving serious airway problem

2. Hypotension, renal dysfunction, and hyperkalemia was reported in both groups 
Table 1 Patients' Demographic (Cont.)

\begin{tabular}{|c|c|c|c|}
\hline & PIONEER HF ${ }^{28}$ & PARAGON HF ${ }^{29}$ & TRANSITION ${ }^{30}$ \\
\hline Year published & 2019 & 2019 & 2019 \\
\hline Study design & $\begin{array}{l}\text { Prospective, multicenter, } \\
\text { double-blind, randomized } \\
\text { controlled trial }\end{array}$ & $\begin{array}{l}\text { Prospective, multicenter, randomized, } \\
\text { double-blind, active-comparator trial }\end{array}$ & $\begin{array}{l}\text { Randomized, multicenter, open-label } \\
\text { study }\end{array}$ \\
\hline No. of patients & 887 & 4822 & 1002 \\
\hline
\end{tabular}
Aim of study Comparing LCZ696 with enalapril in HFrEF patients $(\mathrm{EF} \leq 40 \%)$
Comparing LCZ696 with valsartan in NYHA II-IV HFpEF (EF $\geq 45 \%$ )

Outcome

1. NT-proBNP concentration reduction in LCZ696 was significantly greater than in the enalapril group $(-46.7 \%$ vs $025.3 \%)$ with $\mathrm{p}<0.001$ at week 4 and 8

2. The greater NTproBNP reduction in LCZ696 can be seen as early as week 1

3. The rates of worsening renal function, hyperkalemia, symptomatic hypotension, and angioedema were not between LCZ696 and enalapril

1. The total number of hospitalizations for HF and death from cardiovascular causes was higher in the valsartan-treated vs 690,212 vs 204 , respectively) but they were not statistically significant

2. The change in NYHA class from baseline to 8 months was also $289)$ and less worsened class (202 vs 221)

3. Less change in KCCQ clinical summary score at 8 months in the LCZ696-treated group than the valsartan-treated group

4. Renal composite outcome (decrease in the eGFR $\geq 50 \%$, development of the end-stage significantly different group compared with LCZ696 (797 better in the LCZ696-treated group with a more improved class (347 vs renal disease, or death due to renal failure) was better in the LCZ696treated group (33 vs 64)

5. Valsartan-treated group had more death from any cause (349 vs 342)

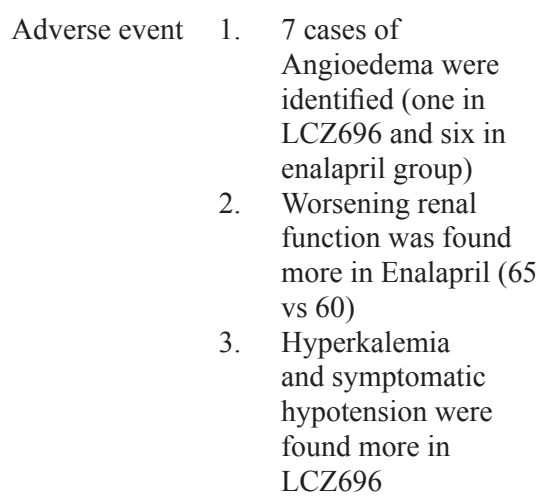

3. Hyperkalemia and symptomatic hypotension were found more in LCZ696

1. 18 cases of Angioedema were identified (14 in LCZ696 and 4 in valsartan group)

2. Elevated serum creatinine, elevated serum potassium, and liver-related adverse event were found more in the valsartan-treated group
Assessing tolerability and optimal time point for initiation (pre-discharge or post-discharge) of LCZ696 in patients stabilized after acute HF

1. The number of patients who achieved the target dose 97/103 $\mathrm{mg}$ twice daily at the end of week 10 was 224 patients in the pre-discharge group (45.4\%) and 248 patients in the post-discharge group (50.7\%)

2. The proportion of patients who achieved and maintained dose $49 / 51$ or $97 / 103 \mathrm{mg}$ twice daily for $\geq 2$ weeks leading to week 10 was $62.1 \%$ in the pre-discharge group and $68.5 \%$ in the postdischarge group

3. The proportion of patients who maintained any dose for $\geq 2$ weeks leading to week 10 was $86 \%$ in the pre-discharge group and $89.6 \%$ in the post-discharge group

4. The permanent drug discontinuations because of adverse events during the 10 week period was higher in the pre-discharge group (7.3\%) compared with the post-discharge group $(4.9 \%)$

1. 3 cases of Angioedema were identified ( 2 in the pre-discharge group and 1 in the postdischarge group), none required hospitalization

2. Hyperkalemia, hypotension, cardiac failure, dizziness, and renal impairment were reported in both groups

Abbreviations: AE, adverse event; EF, ejection fraction; eGFR, estimated glomerular filtration rate; HF, heart failure; HFpEF, heart failure with preserved ejection fraction; HFrEF, heart failure with reduced ejection fraction; KCCQ, Kansas City Cardiomyopathy Questionnaire; NYHA, New York Heart Association 
sacubitril/valsartan. The level of evidence of this study can be considered weak because of the study design. Further research with higher level of evidence is needed to improve the quality of evidence for the usage of sacubitril/valsartan in daily practice.

\section{Conclusion}

NEP played a significant role in degrading vasodilator and cardioprotective agents (NPs, BK, and ADM) which impact on the progression of HF. Inhibiting NEP without inhibiting RAAS did not give a significant and continuous impact on HF patients. Sacubitril/ valsartan by inhibiting both NEP and RAAS reduces the morbidity and mortality of HFrEF patients. As a consequence of inhibiting the pathways; hypotension, renal impairment, and hyperkalemia were reported in the usage of sacubitril/valsartan in clinical trials. Angioedema cases were still reported in patients administered with sacubitril/ valsartan even though the cases were fewer compared to Omapatrilat and most cases were not airway compromise.

\section{Acknowledgement}

The authors thank all who support this review article.

\section{Funding}

None related to this manuscript.

\section{Conflict of Interest}

The author reports no conflicts of interest in this work.

\section{References}

1. Inamdar AA, Inamdar AC. Heart failure: Diagnosis, management and utilization.
J Clin Med. 2016;5(7):62. doi: 10.3390/ jem5070062

2. Choi HM, Park MS, Youn JC. Update on heart failure management and future directions. Korean J Intern Med. 2019;34 (1):11-43. doi: 10.3904/kjim.2018.428

3. Dassanayaka S, Jones SP. Recent developments in heart failure. Circ Res. 2015;117(7):e58-63. doi: 10.1161/CIRC RESAHA.115.305765

4. Yancy CW, Jessup M, Bozkurt B, Butler J, Casey Jr DE, Drazner MH, et al. $2013 \mathrm{ACCF} / \mathrm{AHA}$ guideline for the management of heart failure: A report of the American College of Cardiology Foundation/American Heart Association Task Force on practice guidelines. Circulation. 2013;128(16):e240-327. doi: 10.1161/CI R.0b013e31829e8776

5. McMurray JJV, Packer M, Desai AS, Gong J, Lefkowitz MP, Rizkala AR, et al. Angiotensin-neprilysin inhibition versus enalapril in heart failure. N Engl J Med. 2014;371(11):993-1004. doi: 10.1056/NE JMoa1409077

6. Yancy CW, Jessup M, Bozkurt B, Butler J, Casey DE, Colvin MM, et al. 2017 ACC/AHA/HFSA focused update of the 2013 ACCF/AHA guideline for the management of heart failure: A report of the American College of Cardiology/ American Heart Association Task Force on clinical practice guidelines and the Heart Failure Society of Amer. Circulation. 2017;136(6):e137-161. doi: 10.1161/CIR. 0000000000000509

7. Seferovic PM, Ponikowski P, Anker SD, Bauersachs J, Chioncel O, Cleland JGF, et al. Clinical practice update on heart failure 2019: Pharmacoytherapy, procedures, devices and patient management. An expert consensus meeting report of The Heart Failure Association of the European Society of Cardiology. Eur Heart J. 2019; 21(10):1169-86. doi: 10.1002/ejhf.1531 
8. Barrett A, Rawlings N, Woessner J. Handbook of proteolytic enzymes $3^{\text {rd }}$ ed. Cambridge: Academic Press; 2013.

9. Prausmüller S, Arfsten H, Spinka G, Freitag C, Bartko PE, Goliasch G, et al. Plasma neprilysin displays no relevant association with neurohumoral activation in chronic HFrEF. J Am Heart Assoc. 2020;9(11):e015071. doi: 10.1161/JAHA .119 .015071

10. Sayer G, Bhat G. The renin-angiotensinaldosterone system and heart failure. Cardiol Clin. 2014;32(1):21-32. doi: 10. 1016/j.ccl.2013.09.002

11. Orsborne C, Chaggar PS, Shaw SM, Williams SG. The renin-angiotensinaldosterone system in heart failure for the non-specialist: The past, the present and the future. Postgrad Med J. 2017;93 (1095):29-37. doi: 10.1136/postgradmed j-2016-134045

12. Verbrugge FH, Tang WHW, Mullens W. Renin-angiotensin-aldosterone system activation during decongestion in acute heart failure: Friend or foe? JACC Heart Fail. 2015;3(2):108-11. doi: 10.1016/j. jchf.2014.10.00

13. Dudoignon E, Dépret F, Legrand M. Is the renin-angiotensin-aldosterone system good for the kidney in acute settings? Nephron. 2019;143(3):179-83. doi: 10.1 159/000499940

14. Chopra S, Cherian D, Verghese P, Jacob J. Physiology and clinical significance of natriuretic hormones. Indian $\mathrm{J}$ Endocrinol Metab. 2013;17(1):83-90. doi: 10.4103/2230-8210.107869

15. Volpe M, Carnovali M, Mastromarino V. The natriuretic peptides system in the pathophysiology of heart failure: From molecular basis to treatment. Clin Sci. 2016;130(2):57-77. doi: 10.1042/CS201 5046

16. Baba M, Yoshida K, Ieda M. Clinical applications of natriuretic peptides in heart failure and atrial fibrillation. Int $\mathrm{J}$ Mol Sci. 2019;20(11): 2824. doi: 10.3390/ ijms20112824

17. Ancion A, Tridetti J, Nguyen Trung M-L, Oury C, Lancellotti P. A review of the role of bradykinin and nitric oxide in the cardioprotective action of angiotensinconverting enzyme inhibitors: Focus on perindopril. Cardiol Ther. 2019;8(2):17991. doi: 10.1007/s40119-019-00150-w

18. Hubers S, Kohm K, Wei S, Yu C, Nian H, Grabert R, et al. Endogenous bradykinin and BK1-5 during ACE inhibitorassociated angioedema. J Allergy Clin Immunol. 2018;142(5):1636-9. doi: 10.10 16/j.jaci.2018.06.037

19. Voors AA, Kremer D, Geven C, ter Maaten JM, Struck J, Bergmann A, et al. Adrenomedullin in heart failure: pathophysiology and therapeutic application. Eur J Heart Fail. 2019;21(2): 163-71. doi: 10.1002/ejhf.1366

20. King JB, Bress AP, Reese AD, Munger MA. Neprilysin inhibition in heart failure with reduced ejection fraction: A clinical review. Pharmacotherapy. 2015; 35(9):823-37. doi: 10.1002/phar.1629

21. D'Elia E, Iacovoni A, Vaduganathan M, Lorini FL, Perlini S, Senni M. Neprilysin inhibition in heart failure: Mechanisms and substrates beyond modulating natriuretic peptides. Eur J Heart Fail. 2017; 19(6):710-7. doi: 10.1002/ejhf.799

22. Jhund PS, McMurray JJV. The neprilysin pathway in heart failure: A review and guide on the use of sacubitril/valsartan. Heart. 2016;102(17):1342-7.

23. Braunwald $E$. The path to an angiotensin receptor antagonist-neprilysin inhibitor in the treatment of heart failure. J Am Coll Cardiol. 2015;65(10):1029-41. doi: 10.1016/j.jacc.2015.01.033

24. Langenickel TH, Dole WP. Angiotensin receptor-neprilysin inhibition with LCZ696: A novel approach for the 
treatment of heart failure. Drug Discov Today Ther Strateg. 2012;9(4):e131-9. doi: 10.1016/j.ddstr.2013.11.002

25. Ayalasomayajula S, Langenickel TH, Chandra P, Wolfson ED, Albrecht D, Zhou W, et al. Effect of food on the oral bioavailability of the angiotensin receptor - neprilysin inhibitor sacubitril/valsartan (LCZ696) in healthy subjects. Int J Clin Pharmacol Ther. 2016;54(12):1012-8. doi: $10.5414 / \mathrm{CP} 202604$

26. Solomon SD, Zile M, Pieske B, Voors A, Shah A, Kraigher-Krainer E, et al. The angiotensin receptor neprilysin inhibitor LCZ696 in heart failure with preserved ejection fraction: A phase 2 double-blind randomised controlled trial. Lancet. 2012;380(9851):1387-95. doi: 10.1016/S 0140-6736(12)61227-6

27. Senni M, McMurray JJV, Wachter R, Mclntyre HF, Reyes A, Majercak I, et al. Initiating sacubitril/valsartan (LCZ696) in heart failure: results of TITRATION, a double-blind, randomized comparison of two uptitration regimens. Eur J Heart Fail. 2016;18(9):1193-202. doi: 10.1002/ ejhf.548

28. Velazquez EJ, Morrow DA, DeVore AD, Duffy CI, Ambrosy AP, McCague K, et al. Angiotensin-neprilysin inhibition in acute decompensated heart failure. N Engl J Med. 2019;380(6):539-48. 10.105 6/NEJMoa1812851

29. Solomon SD, McMurray JJV, Anand IS, Ge J, Lam CSP, Maggioni AP, et al. Angiotensin-neprilysin inhibition in heart failure with preserved ejection fraction. N Engl J Med. 2019;381(17):1609-20. doi: 10.1056/NEJMoa1908655

30. Wachter R, Senni M, Belohlavek J, Straburzynska-Migaj E, Witte KK, Kobalava Z, et al. Initiation of sacubitril/ valsartan in haemodynamically stabilised heart failure patients in hospital or early after discharge: Primary results of the randomised TRANSITION study. Eur J Heart Fail. 2019;21(8):998-1007. doi: 10.1002/ejhf.1498 